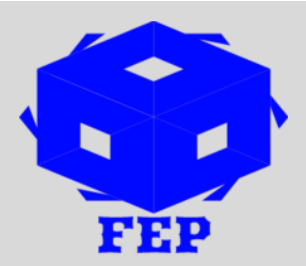

\title{
BANKS' LENDING PREFERENCES AND SME CREDIT IN PAKISTAN: EXPERIENCE AND WAY FORWARD
}

\author{
Saddam Ilyas ${ }^{1}$ \\ ${ }^{1}$ Economic Analyst, Research Department, State Bank of Pakistan, Karachi, Pakistan
}

*Corresponding Author: Saddam Ilyas

Corresponding Author Email: saddam.ilyas@sbp.org.pk

Article Received: 16-06-19 Accepted: 25-07-19

Published: 05-09-19

Licensing Details: Author retains the right of this article. The article is distributed under the terms of the

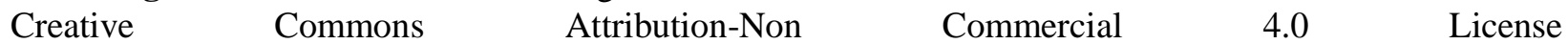
(http://www.creativecommons.org/licences/by-nc/4.0/) which permits non-commercial use, reproduction and distribution of the work without further permission provided the original work is attributed as specified on the Journal open access page.

\section{ABSTRACT}

This analysis builds on the evidence that Pakistani banks (as of June 2017) have sufficient financial resources to lend at levels that would be helpful for SMEs at large. Channelization of this excess banking liquidity to SMEs can lead to investment in innovative and lucrative projects to stimulate employment and growth in a number of important industries. However, banks are found reluctant to finance to SMEs owing the opacity issues and related risk. Mitigation of this problem nonetheless demands that banks should take leaps in adopting progressive/modern lending techniques (which bode well for the modern financing needs of SMEs) banks (without compromising on risk and return) can more adequately address SME credit constraints.

Keywords: Opacity issues; Banks' lending behavior; SMEs; Modern financing.

JEL Classification: D81; G24; L11; G32

\section{INTRODUCTION}

Bottlenecks associated with financing of Small and Medium Enterprises (SMEs) is a topic which has gained vital interest of central bankers around the globe. The conceptual framework to which most of the contemporary research adheres has been quite helpful in understanding the institutions and markets that provide funds to SMEs. It has also provided insights into the effects of policies that affect access of credit to SMEs. SME credit is seen risky by lenders in general, which results in less product innovation for the segment. Particularly in developing countries, 
banks lack motivation to opt for innovative lending techniques required to serve the under- or un-served SMEs. Although literature shows that innovation in lending techniques can prove vital to boost SME financing. This write-up asserts that even in Pakistan, adoption of progressive techniques can redeem the banking sector confidence via mitigation of the opacity issues associated with SMEs countrywide.

In Pakistan, SMEs constitute about 90 percent of businesses and employ around 80 percent of the non-agricultural labor. SMEs contribute more than 40 percent in the annual GDP and around 27 percent in total exports (Saleem, 2008 and Dar et al., 2017). Owing to significant diversification countrywide, SMEs are also the outsourcing hubs of large corporations. If SMEs are engines to growth, then credit is the lifeline of SMEs, but unfortunately, overtime (FY-05 to FY-17) the significant unbundling in the banks' SME lending has undermined their growth.

Formal financing to SMEs has remained low due to limited access and understanding of financial products. Besides lack of collateral, most of the SMEs don't possess necessary documentation to get credit. As largely banks are not willing to take exposure because SMEs don't have a credit history. The lenders have developed strong obsession with collateralized lending that leaves little space for improvement in existing lending techniques. However, over the past decade, market regulators are striving hard to boost up SME financing to make these enterprises growth engines. Accordingly, various policy interventions have been carried on in the past to incentivize banks for SME lending. These include: improved regulatory framework, credit guarantee schemes, mark-up subsidy, risk coverage schemes and annual SME lending targets. Despite all these efforts, SME credit remains low, and this problem can partially be attributes to lack of product innovation on part of banks.

Even though banks remain obsessed with collateralized lending ${ }^{1}$, SMEs credit constraints can be addressed through heterogeneous transactions lending techniques which include: (i) financial statement lending; (ii) asset-based lending; (iii) factoring; (iv) fixed-asset lending; (v) small business credit scoring; (vi) leasing; and (vii) agent-based lending. Except financial statement lending, other techniques can be vital to target opaque and tyro SMEs. In addition to transactions lending, other techniques (based on qualitative/soft information) can also systematically overcome the opacity issues particularly associated with SMEs. These include: relationship lending and agent-based lending. This way, sustained availability of credit can make SMEs engines to economic growth by enabling them to invest in innovative and high return projects that can drive employment and growth in a number of important industries countrywide. Furthermore, SMEs' opacity issues can be minimized via improving and making public the existing e-CIB ${ }^{2}$ data available with the central bank. It can provide more leverage to private credit bureaus ${ }^{3}$ in terms of precision of their credit ratings.

\footnotetext{
${ }^{1}$ Historically about 98 percent of private sector credit has been targeted through collateralized lending.

${ }^{2}$ The Electronic Credit Information Bureau (e-CIB) was established with the State Bank of Pakistan in 1992. Ever since its inception, e-CIB has been playing a pivotal role in gathering, organizing and disseminating critical information relating to credit-worthiness of borrowers to assist financial institutions in their lending decisions and averting the occurrence of default. Existing e-CIB system has been designed in line with best
} 


\section{Banking Preferences and Formal Financing to SMEs}

Although, interest rates are at historic low (end June 2017), credit to private sector is not picking up with the required acceleration. Overtime, private sector credit as a percentage of GDP has followed a declining trajectory as shown in Figure 1(d). At present, it is hovering around 16 percent that is lower even if compared to other emerging market economies of the region (for more explanation, see Khalid \& Nadeem, 2017) ${ }^{4}$. This shows that banks are inefficiently channelizing credit to private sector, out of which SME financing is a small fraction (SME credit has dropped from 17 percent of private sector credit in FY-05 to only 8 percent in FY-17).

Historically, banks have been deploying saving deposits to maximum banking spread ${ }^{5}$, as shown in Figure 1 (b). Banking spread in Pakistan has remained higher even in comparison to other

emerging market economies (Khalid \& Nadeem, 2017). As extraordinary banking spread can possibly lower the competition and efficiency in the banking sector. In order to discourage this

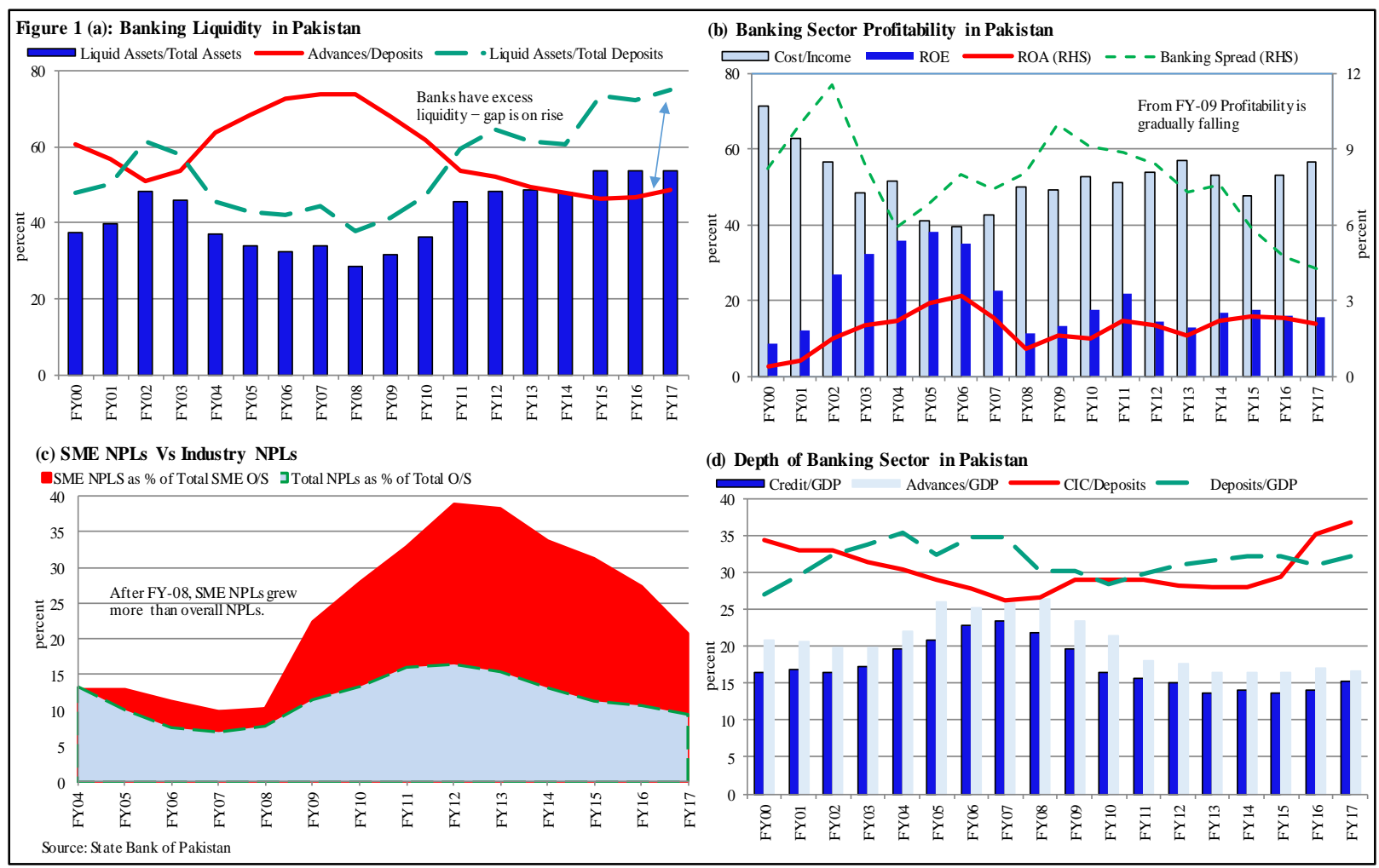

practice, the State Bank of Pakistan (SBP) has followed a narrow interest rate corridor regime since 2009. Banks are now left with fewer options that can yield windfall gains i.e. spread

international credit sharing practices around the world. The e-CIB database is capturing more than 4 million borrowers' records collected and submitted by about 100 member financial institutions.

${ }^{3}$ In Pakistan there are four privately owned and managed credit bureaus that facilitate lenders with credit information to screen and monitor borrowers. These are: 1) Datacheck (Pvt.) Limited, 2) News-VIS Credit Information Services (Pvt.) Limited, 3) ICIL/ PakBizInfo and 4) Credit Chex (Pvt.) Limited.

${ }^{4}$ The private sector credit growth in Pakistan appears to have deteriorated over time.

${ }^{5}$ Bank spread is the simple difference between the prevailing weighted average borrowing rate and weighted average lending rate at commercial banks. 
maximization. ${ }^{6}$ They can neither cut-down structural/operational costs nor can they earn enough by lending to risk averse avenues. ${ }^{7}$ All these circumstances provide justification for banks to endeavor in SME lending.

In Pakistan, banks' prime function is cost minimization. To meet this end, banks either engage with big corporates or prefer sovereign lending. By going into risk free ventures, banks are trying to avoid rather than managing various risks. ${ }^{8}$ This risk averse behavior is although against the banking spirit, but banks find sovereign lending more convenient against lending to private sector where efforts are required to monitor and assess associated risks. However, this behavior defies the basic cause of existence of banking establishments i.e. by default, they should manage risk rather than avoiding it. Owing to availability of risk free lending avenues, commercial banks have attained cost efficiency at the expense of inclusivity. ${ }^{9}$

In recent years (particularly after FY-08), trend of banking deposits to GDP ratio has remained stable, whereas private sector advances to GDP is slightly declining (Figure 1d). However, the overall supply of credit (to public plus private sector) has considerably improved by the banks. So, less credit being supplied to private sector (or to SMEs) means either banks are facing challenges at channelization front or they are deliberately shying away from SME lending. Later phenomenon has been more apparent in recent decade (FY-08 to FY-17). Banking credit has been highly skewed towards sovereign lending and/or banks are mostly serving the borrowing needs of the already existing corporate client. After FY-08, commercial banks' investments have been more bulged towards government treasury bills as they are facing obvious trade-off between risk and return especially in the wake of prolonged accommodative monetary policy

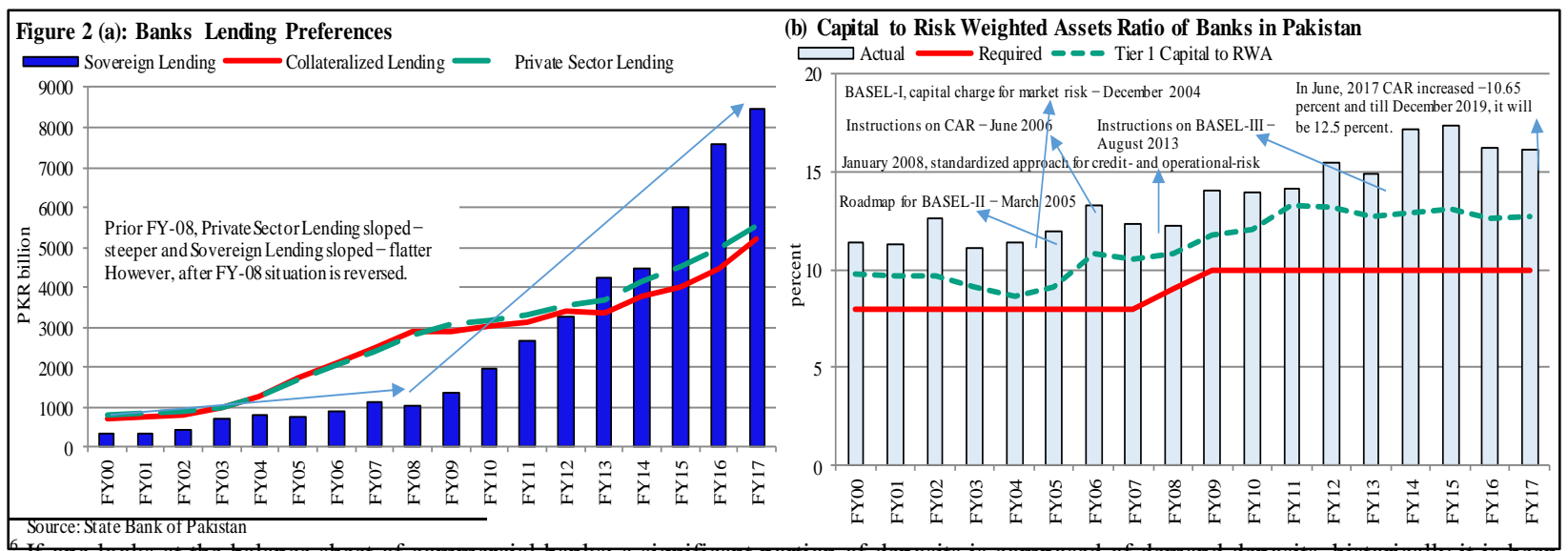

If one looks at the batance sheet of commercial banks; a significant portion of deposits is composed of demand deposits, historicalty it is been about 80 percent if taken as a percentage share of total deposits. With all due good reasons, these deposits come at negligible price on the end of commercial banks i.e. just maintenance and operational facilities to current account holders. In order to remain liquid commercial banks can't deploy demand deposits for long-term i.e. either private lending or PIBs. Most lucrative option left with commercial banks is to invest these funds in short-term, secure and less costly avenues i.e. MTBs. That's why; banks are deploying these funds by investing in MTBs and/or playing in money market for gains over shorter periods. Since November 2013, SBP has followed accommodative monetary policy in order to benefit from lower inflation as growth stimulation has overridden the inflation targeting objective. This shrinking spread has resulted in negligible roll-over of long-term sovereign lending i.e. PIBs. Furthermore, stringent regulatory requirements also restrict banks to lend to opaque enterprises in private sector.

${ }^{7}$ As owing to low markup, growing industrial competition does not allow them to lower down salaries of managing staff or to restrain from opting for technological advancements that include the expenses on customized banking software suits.

${ }^{8}$ These various risks are credit risk, default risk, market risk and interest rate risk etc.

${ }^{9}$ Over the horizon, financial sector has gained cost efficiency at the expense of financial inclusion. As the most vulnerable segment (SMEs and small \& rural enterprises) largely remain excluded from the financial sector. 
that has been adopted by SBP in order to stimulate growth and benefit from lower inflation. After heavily investing in MTBs, relatively smaller split of advances is left for private sector (Figure 2a), which is to be served to a handful of industries at the expense of financial inclusion at large; which further adds to the financing problems of SMEs.

As shown in Figure 2(a), banks have been strongly obsessed with collateralized lending which often excludes new but potentially innovative borrowers. About 97 percent of lending to private sector in Pakistan is collateral based. Furthermore, stringent documentation and evaluation requirements limit timely and affordable credit to SMEs. Rather than serving small loans to various customers, banks prefer to lend few big loans to corporate entities easily meeting lending requirements i.e. easily assessable good quality collateral. This way, banks keep on saving on monitoring and operational costs by rendering SMEs under-served at large. By saving on transaction and monitoring costs, banks have ended up with cost efficiency where financial inclusion i.e. the equitable channelization of credit has remained a wild goose chase.

Figure 2(b) indicates the robust regulatory framework which although has brought efficiency (as actual CAR has been far greater than required) in the banking industry but it has also been one of the reasons of lower private sector credit to GDP (a compromise on the equity side). As banks have to maintain additional liquidity as a preemptive measure to meet the proposed regulations. In pursuit of compliance to regulations, banks have reluctantly gained excess liquidity as revealed by actually higher than required capital adequacy ratio (CAR). Under BASEL-I, capital charge for market risk was effectively imposed in December 2004 whereas, a roadmap for BASEL-II was announced in March 2005; and further instructions on CAR were issued in June 2006. From January 2008, BASEL-II was implemented in full essence and a standardized approach was adopted for credit- and operational-risk. Instructions on BASEL-III were issued in August 2013, after which under compliance status as of June 2017, minimum requirement of CAR was increased from 10 percent to 10.65 percent. Furthermore, as part of the ongoing phased implementation plan, CAR requirements and capital conservation buffers are to be gradually raised to 12.5 percent by the end of December 2019. In addition, from August 2009, SBP has followed a narrow interest rate corridor regime which has resulted in contraction of banking spread. Rigorous regulatory requirements impose an implicit taxation on banking sector and further constrain the SME credit. As from FY-09 onward, banks are continuously shedding on profitability grounds (Figure 1b).

\section{INDIGENOUS EXPERIENCE OF SMES}

SMEs have strong association with both formal and informal sectors. At times of distress, they are more resilient owing to backward- and forward-linkages and concentration of industry specific SMEs in a typical geographic jurisdiction. On the flip side, this resilience is also the result of hereditary businesses, labor intensive production techniques, poor management practices, and lack of innovations. Lack of adequate financing facilities instigates SMEs 
vulnerability to external shocks particularly at financial fronts (refer to low financing; low productivity; and low revenue trap). Unfortunately, overtime (FY-05 to FY-17) the significant unbundling in the banks' SME lending has undermined their growth. During this span, SME credit has gone through significant changes i.e. declining from about 17 percent of private sector credit in FY-05 to mere 8 percent in FY-17. The indigenous experience of SME financing can be divided into three phases - explained below.

\section{Phase-I: Pre FY-08}

Until FY-08, in the hindsight of a huge influx of liquidity, the banking sector took leaps and significantly expanded the services suit offered to SMEs besides aggressively venturing in other non-conventional areas - the consumer finance. In the presence of the government's subdued appetite for budgetary funding, banks appeared desperate to park their funds with private sector, especially the SMEs. Around this period, easy monetary policy also ensured incentive to SMEs to borrow credit from banking channel. This resulted in heating-up of credit demand; increasing SME financing as a percentage share of private sector credit to about 17 percent in FY-05 (all time high as reported in Figure 3a). Overall, this phase was marked with enabling environment for healthy growth of private sector credit where SMEs were quite benefiting from all extended favorable factors.

\section{Phase-II: FY-08 to FY-14}

Things began to change course from 2008 onwards, following the deterioration in the overall macroeconomic and investment climate globally that brought commodity prices slump. Not only did the global financial crisis (GFC) triggered a sense of uncertainty, but also the growing security concerns, political instability and energy shortages in the country significantly dented domestic business prospects by wiping out the enabling environment and slacking the confidence of economic agents at large. Banking sector profitability squeezed, as average return on assets decreased from 2.3 (during FY-02 to FY-07) to 1.4 (during FY-08 to FY-14). SMEs also witnessed a sharp increase in NPLs, which mounted from average 12 percent (pre FY-08 period) to 30 percent of outstanding SME lending during this span; lowering the average SME credit to mere 7.65 percent of the overall private sector credit from FY-09 to FY-14 (Figure 3d). During this period, double-digit interest rates also undermined to SME credit growth. 


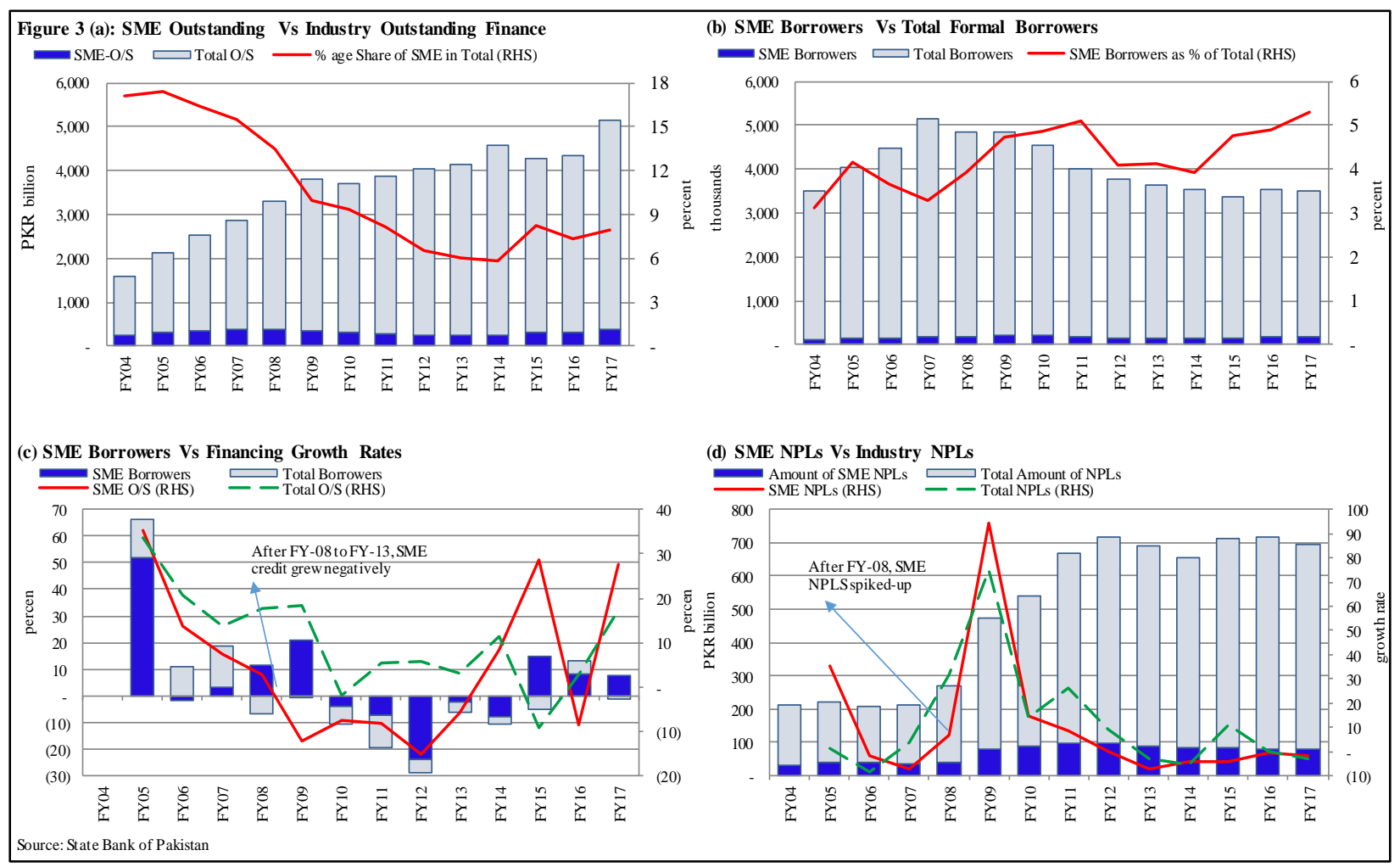

Subsequent to almost half decade of continuous war on terror, financial inflows also become bleak. To end broadly looming uncertainty, counter-cyclical macroeconomic policies could not be deployed as vulnerabilities in the external sector morphed into a full-blown balance of payments crisis in FY-08. For the following 5 years, interest rates remained in double-digits contributing to an anemic SME credit growth. In this period, crowding out of SME sector occurred as political instability and conduct of general elections (in 2008) increased government borrowing from financial sector.

\section{Phase-III: Post FY-14}

In the post FY-14 period, as the recessionary shocks of global meltdown are almost fading away, banks are gradually taking exposure in SME financing. Although, the average SME credit to private sector credit has remained at 7.86 percent, but rising aggregate demand and presence of fairly accommodative monetary policy will result some improvements in SME credit takeoff going forward. For the most part, improving macroeconomic environment also indicates future prospects for SMEs as the SBP is spearheading commendable efforts in this regard.

If articulated by the Large Scale Manufacturing (LSM), businesses are expanding at a considerable pace and going forward they would need financing to keep it up. ${ }^{10}$ In the wake of

\footnotetext{
${ }^{10}$ In FY-17, LSM posted a ten-year high growth of 5.7 percent. However, large imbalances at external front and extending skirmishes at political front can be injurious to macroeconomic stability down the road. Which resultantly can disturb the smooth and sustained credit availability to SMEs.
} 
accommodative monetary policy, SMEs are in better position to borrow for much needed BMR ${ }^{11}$ requirements besides working capital. However, they are still struggling despite improved aggregated demand contributing to consumption led growth. ${ }^{12}$ This slowdown in SME credit growth is perhaps due to banks' skepticism developed in Phase-II.

Table 1

Sectoral Weighted Average Lending Rate (WALR) of Banks

\begin{tabular}{clc}
\hline S.\# & Sector & $\begin{array}{c}\text { WALR } \\
\text { (Jun-17) }\end{array}$ \\
\hline 1 & Government & \\
2 & Corporate & 6.7 \\
& Commercial & 7.0 \\
3 & Agriculture & 12.4 \\
4 & SME/Consumer & $14.7^{*}$ \\
& Finance & \\
\hline
\end{tabular}

Source: State Bank of Pakistan

*authors' calculation

Table (1) clearly shows that SME lending is relatively more profitable as compared to other avenues available with banks. However, it is obviously one of the riskier venture; given the current SME lending portfolio. This means, appropriate risk assessment can prove vital for more credit availability to SME sector. Moreover, given the ongoing favorable environment, SME lending is likely to pick-up. As, economic activity is improving; lending rates are at historic low. Businesses are reaping handsome profits owing to multiple price revisions, better aggregate demand and improved global commodity prices. ${ }^{13}$ The economy is likely to observe further expansion in the wake of ongoing CPEC related projects. ${ }^{14}$ Down the road, power outages are likely to end owing to completion of various mega projects undertaken by the public and/ or private sector. In the wake of these positive developments, perhaps the banks will gradually change their game regarding credit injections to potential SMEs. As banks can benefit by venturing in SME lending, one way to grease these engines of economic growth is to improve the existing lending techniques and opt for modern lending practices that are beyond collateralized lending.

\section{HOW TO GREASE THE GROWTH ENGINES?}

Even if banks have comfort with collateralized lending, adoption of progressive lending techniques can still enhance the SME credit. This simply involves improvement in existing lending techniques besides, adoption of qualitative techniques. These techniques, if employed,

\footnotetext{
${ }^{11}$ BMR stands for balancing, modernization and replacement. It usually refers to efficiency enhancement of business entities.

${ }^{12}$ In FY-17 growth (5.3 percent) major driving force was consumption. Largely Pakistan remains a consumption-oriented society, where marginal propensity to consume (MPC) remains highest. Referred to Khan et al., 2015 long-term MPC in Pakistan is 0.82 that is greater than that of India (0.72), and Bangladesh (0.75).

${ }^{13}$ In Pakistan, the median number of price changes is three times of what is found in developed world (details are available in Ali et al., 2016).

${ }^{14}$ China-Pakistan Economic Corridor is a collection of about 52 infrastructure development projects under public-private partnership. Current net worth of projects under CPEC is 62 billion of US dollar.
} 
can serve the borrowing needs of underserved SMEs. In addition, as information and communication technology (ICT) is swiftly growing up. Acquiring soft information has become easy. In Pakistan, significant penetration of smart phone and usage of mobile internet has resulted in social networking through various applications (facebook, whatsapp, twitter, linkedIn and Instagram etc.), which in near future can be taped to promote qualitative lending. These progressive lending techniques are explained below:

\section{Financial Statement Lending}

Financial statement lending is a transactions technique under which lending decisions are primarily based on the soundness (reliability plus strength) of a borrower's financial statements. It purely relies on hard information that is subjected to two conditions; as per necessary condition: the borrower should have informative financial statements audited by some reputed accounting firm based on generally accepted accounting principles (GAAP); and according to sufficient condition: these financial statements must reflect strong financial position easily calculated from financial ratios. Through scrutiny of quantitative information, lender can effectively assess the expected future cash flows of targeted SMEs as being the primary source of repayment of loan. In Pakistan, it is interesting to know that in top ten SME sectors more than 80 percent of firms prepare financial statements but none get these audited. ${ }^{15}$ It necessitates sound financial reporting as per standard practices that can play a vital role in improving the credit availability from formal sector to SMEs.

\section{Asset-based Lending}

Asset-based lending focuses on the quality of assets (principally accounts receivable and inventory) of SMEs, which are (being the primary source of repayment) pledged as collateral with the bank. ${ }^{16}$ This way, even opaque SMEs can meet their working capital requirements. The amount of credit extended through asset-based lending is systematically linked with the net market worth of assets pledged with the lending bank. This requires appropriate assessment of collateral over continuous intervals, i.e. daily in the case of accounts receivable, and weekly or monthly for inventory. Over each assessment period, banks assure that the liquidation value (simply the net market worth) of the collateral must exceed the credit exposure taken (Berger \& Udell, 2006). Asset-based lending can be quite successful in case of Pakistan where, around 70 percent of the SME borrowing needs are related to working capital. It will also provide borrowing opportunity to people who desist traditional loans owing to religious reasons.

\section{Factoring}

Factoring involves the purchase of accounts receivable by the lender called factor. Similar to asset-based lending, factoring also focuses on the net value of an underlying asset, rather than the

\footnotetext{
${ }^{15}$ International Finance Corporation (IFC) in liaison with State Bank of Pakistan mandated Grant Thornton Pakistan to conduct a primary survey of businesses within the top ten SME sectors/subsectors of Pakistan in 2010 to determine banking and financial needs of these sectors.

${ }^{16}$ The pledging of accounts receivable or inventory does not distinguish asset-based lending from the other lending techniques that can also involve collateralized lending. For example, financial statement lending, relationship lending, and credit scoring etc., where collateral is used as secondary source of repayment whereas, under asset-based lending the extension of credit is based on the net market worth of the collateral, rather than the overall creditworthiness of borrowing SME.
} 
overall value/ risk of the firm. However, it involves the financing of accounts receivable, where the underlying asset is sold to the lender. It is essentially a bundle of three financial services: a financing component, a credit component and a collections component. Under most factoring arrangements, the borrower outsources its credit and collections activities in addition to obtaining financing. Factoring can effectively address the opacity problem by focusing primarily on the quality of the obligor, rather than the owner and/or SME. ${ }^{17}$ It can be a successful trade finance facility in Pakistan.

\section{Fixed-asset Lending}

Fixed-asset lending focuses on assets that are long-lived and are not sold in the normal course of business (e.g. machinery, building and land). Under fixed-asset lending the underlying assets are pledged to the lender as collateral. However, the pledged assets under fixed-asset lending are exclusively identifiable. The long life and unique identification of fixed assets leads to very different underwriting procedures, contract structures, and monitoring mechanisms. The contract structure specifies an initial loan-to-value ratio less than unity. It also involves setting a loan amortization schedule with a final maturity less than the estimated lifespan of the asset. This contract structure also feeds back to the underwriting process, where the primary financial analysis focuses on coverage ratios that measure a firm's ability to meet the amortization schedule (i.e., debt servicing). Owing to easy monitoring, fixed-asset lending is one of the easiest ways to finance the SMEs, which do not bear any credit history. ${ }^{18}$ Currently, it is the most common facility for SME financing in Pakistan.

\section{Leasing}

Leasing involves the purchase of fixed assets by the lender: known as a lessor. Leasing is a very common practice used by banks to finance for equipment, motor vehicles, and real estate in many countries. The lessor purchases the fixed assets and then simultaneously enters into a rental contract with the lessee that specifies the payment schedule. The contract often contains an option whereby the lessee can purchase the assets at the end. Leasing can effectively overcome the opacity issues attached with SMEs because the underwriting decision is primarily based on the value of the asset being leased. ${ }^{19}$ It has been very successful in Pakistan - in particular reference to financing the consumer durables.

\section{Small Business Credit Scoring}

Small business credit scoring is also a transactions technique based primarily on hard information about the SME and its owner. The owner specific information is primarily personal

\footnotetext{
${ }^{17}$ The use of factoring varies widely across countries. For example, the ratio of the volume of factoring to GDP in 2002 was 11.9 percent in Italy, but only 0.9 percent in Switzerland (Berger \& Udell, 2004).

${ }^{18}$ Unlike monitoring asset-based loans, the monitoring of collateral (i.e. ownership of collateral by the borrower) is not problematic in fixed-asset lending. The borrower can only sell a fixed asset by transfer of title, which can only occur if the lender agrees to release the lien. Monitoring the borrower's ability to pay (i.e. its cash flows) is tied to the observation of timely repayment as specified by the amortization schedule. Failure to meet a required payment signals inadequate cash flow and triggers default risk on the loan.

${ }^{19}$ Leasing can mitigate an adverse selection problem, either in the used equipment market by encouraging a higher quality of product sold or offlease (i.e. sold by lessors when the purchase option is not exercised) or in the new product market (for more details visit Gilligan, 2004).
} 
consumer data obtained from consumer credit bureaus (e-CIB data in case of Pakistan). Data dissemination to privately owned credit bureaus helps them in determining the credit rating of various borrowers that facilitate lenders to screen and monitor a particular loan applicant. This combined with data on the SME (collected by the financial institutions) is then entered into a loan performance prediction model, which yields a score to determine the approval or disapproval of loan application. ${ }^{20}$ Besides default levels, existence of credit bureaus also reduces the cost and time to process loan application (Miller, 2003). Credit ratings can be vital to finance SMEs based on their projected sales or future cash flows.

\section{What Lies Beyond Transactions Lending?}

\section{Relationship Lending}

Relationship lending can specifically be targeted to SMEs to address their opacity issues, as the financial institutions rely primarily on soft information gathered over time through interactions with an SME, its owner and the local community or industry under which a business operates. This information is largely acquired by the loan officer through direct contacts with the borrower and by observing the SME's performance on all dimensions of its banking relationship. By acquiring this soft information, the banks can make an assessment of the future prospects of SMEs based on past communication with SMEs, their customers, suppliers, or the industry peers. Previously, preservation of this soft information was difficult as this may often remain proprietary to the loan officer because it is not easily observed, verified, or transmitted to others (Degryse \& Van Cayseele, 2000). Despite being a potential product for SME financing, relationship lending remains untapped due to banker-borrower divide in Pakistan.

\section{Agent-based Lending}

A pervasive concern faced by the banks is careful risk evaluation of the SMEs aiming to design their sector specific market strategies. However, owing to opacity issues, banks found SME lending the riskiest venture. Agent-based lending can overcome this problem via mitigation of risk factor primarily associated with such financing. This kind of lending can raise the confidence of banking sector while lending to SMEs as, this requires a third party for evaluation, monitoring and loan payback. This way, banks can save on evaluation and monitoring costs by outsourcing such activities to their agents who also bear the prime liability in most of the cases. However, agents only help in evaluation and monitoring whereas, repayment liability lies with the borrower. In recent years, various organizations are running randomized control trails to gauge the success of agent-based lending in Pakistan.

\footnotetext{
${ }^{20}$ Across the globe, small business credit scoring models are being widely relied to target opaque SMEs for a range of credit requirements, normally small amount loans that are rated as relatively riskier, but bear high interest rates, and are often located outside of the banks' local markets (Frame \& Woosley, 2004). This technique is relatively new in the sense that it was not generally used in the United States until the mid1990s (Berger \& Udell, 2006). In US, most banks use external vendors to create the scores, and these vendors rely on credit bureaus that share consumer and business information and financial institutions to share their loan performance data to estimate the model (Miller \& Rojas, 2004).
} 


\section{CONCLUSION AND RECOMMENDATIONS}

Keeping in view the banking liquidity situation, especially after FY-14, it can be inferred that banks have sufficient resources to lend at levels that would help SMEs to invest in innovative and lucrative projects to drive employment and growth in a number of important industries. For banks to increase their SME lending, a novel framework is proposed regarding lending techniques and lenders' feasibilities to finance SMEs in Pakistan. By adopting progressive lending techniques which bode well with the modern financing needs of SMEs at large, banks (without compromising on risk and return) can do more in order to address SME credit constraints. In order to make SMEs engines to growth, adequate financing is necessary. As availability/unavailability of sustained credit can make SMEs grow/go as engines to economic growth.

Currently, as banks are reluctant to opt for these progressive lending techniques, efforts are required to soften banks' skepticism about SME lending in the near future. Since, SBP (after declaring SME a priority sector) is spearheading appreciable efforts to promote SME finance, it should lead this drive by facilitating banks to adopt progressive lending techniques that are essential to design innovative products to target on SMEs. SBP may call on banks through awareness sessions, expert to banker talks, and joint capacity building ventures to improve SME credit. Banks that aggressively venture in SME financing may be incentivized by allowing some relief in CAR. Furthermore, by venturing in SME sector, banks may additionally gain from the SBP refinance schemes. Adoption of these techniques can be self-motivating, as banks are forgoing handsome profits that can be reaped otherwise by deploying the excess liquidity in SME financing.

\section{References}

Berger, A.N. and Udell, G.F., (1994). Did risk-based capital allocate bank credit and cause a" credit crunch" in the United States? Journal of Money, credit and Banking, 26(3), pp.585628.

Berger, A.N. and Udell, G.F., (2006). A more complete conceptual framework for SME finance. Journal of Banking \& Finance, 30(11), pp.2945-2966.

Choudhary, M.A., Faheem, A., Hanif, M.N., Naeem, S. and Pasha, F., (2016). Price setting \& price stickiness: A developing economy perspective. Journal of Macroeconomics, 48, pp.44-61.

Dar, M.S., Ahmed, S. and Raziq, A., (2017). Small and medium-size enterprises in Pakistan: Definition and critical issues. Pakistan Business Review, 19(1), pp.46-70.

Degryse, H. and Van Cayseele, P., (2000). Relationship lending within a bank-based system: Evidence from European small business data. Journal of financial Intermediation, 9(1), pp.90-109. 
Frame, W.S. and Woosley, L., (2004). Credit scoring and the availability of small business credit in low-and moderate-income areas. Financial Review, 39(1), pp.35-54.

Gilligan, T.W., (2004). Lemons and leases in the used business aircraft market. Journal of Political Economy, 112(5), pp.1157-1180.

Khalid, A. and Nadeem, T., (2017). Bank Credit to Private Sector: A Critical Review in the Context of Financial Sector Reforms. Available: http://www.sbp.org.pk/publications/staff-notes/BankingReforms.pdf.

Khan, K., Anwar, S., Ahmed, M. and Kamal, M.A., (2015). Estimation of Consumption Functions: The Case of Bangladesh, India, Nepal, Pakistan and Sri Lanka. Pakistan Business Review, 17(1), pp.113-124.

Miller, M. and Rojas, D., (2004). Improving access to credit for smes: an empirical analysis of the viability of pooled data sme credit scoring models in Brazil, Colombia \& Mexico. World Bank working paper.

Saleem, S., (2008). SMEDA SME Policy paper 2007-A Critical Review (An analytical commentary upon SME policy proposed by SMEDA Pakistan). 